\title{
THE RE-CODIFICATION OF THE SLOVAK CIVIL PROCEDURE CODE WITH A SPECIAL EMPHASIS ON REMEDIAL MEASURES
}

\author{
Marek Števček \& Dominika Malá ${ }^{1}$
}

\section{Faculty of Law, Comenius University in Bratislava, Slovakia Ministry of Justice of Slovak Republic email: marek.stevcek@flaw.uniba.sk}

ŠTEVČEK, Marek; MALÁ, Dominika. The Re-Codification of the Slovak Civil Procedure Code with a Special Emphasis on Remedial Measures. International and Comparative Law Review, 2013, Vol. 13., No. 1, pp. 121-135.

DOI: 10.1515/iclr-2016-0063.

\begin{abstract}
This analytical paper focuses on the ongoing works on the recodification of the law of civil procedure in Slovakia. The paper introduces and presents the most relevant changes to the Slovak Civil Procedure Code and offers the closer examination of the reform of remedial measures included in the re-codification proposal.
\end{abstract}

Keywords: Civil procedure law, Slovak Republic, re-codification works, remedial measures.

\section{Introduction}

Civil procedure is most frequently characterized as a procedural activity or the procedure of a court, parties to a case and other subjects and persons participating in the proceedings, the aim of which is providing the protection of subjective rights and interests protected by the law. It is also possible to use a different definition to characterize the civil procedure which defines civil procedure not only as an activity, but also as procedural relationships which are formed when the aims of the basic procedural goals are reached.

In Slovakia the civil procedural law is mainly regulated through the Civil Procedure Code from 1963. Despite the legislator's attempts to modernize and enhance the Procedure Code it is not possible to consider it as a modern regulation of the $21^{\text {st }}$ century meeting the requirements and criteria for a good quality fundament for reaching an effective court procedure.

1 Marek Števček is an Associate Professor at Department of Civil Law, Faculty of Law, Comenius University in Bratislava, Slovakia and Chairman of the Re-Codification Committee for the Civil Procedure Code, Ministry of Justice of Slovak Republic. Email: marek.stevcek@flaw.uniba.sk Dominika Malá is Secretary of the Re-Codification Committee for the Civil Procedure Code, Ministry of Justice of Slovak Republic. 
The Civil Procedure Code has been amended almost eighty times, which has caused content as well as logical discontinuity of the individual sections of this Code. It is not possible to cover all the provisions connected with the corresponding procedural institutes or in other words they can only be covered partially. The partial amendments brought many provisions (so called procedural provisions) into the Civil Procedure Code which contributed to its rather inconsistent inner structure thus making the basic civil procedure more chaotic. Many provisions have been cancelled, many others are obsolete and those procedural institutes which would deserve a special attention and which should be covered in a special part if not in a special code have been placed at the end of the specific sections. On the other hand some procedural institutes which in fact do not have to be a part of procedural code, are regulated in a special part of the code (such as e.g. other activities of a court).

The current Civil Procedure Code does not only suffer from the formal deficiencies, such as fragmentation and incoherency of the legal regulation. There are also such provisions which are practically not in use and thus it is not necessary to include these provisions in the Procedural Code. On the contrary the practical experience has proved that there are some institutes which are not reflected in the Slovak legal regulation. However, based on the knowledge of history and the comparison with other legal regulations it is obvious that these institutes should be introduced.

The reasons and causes of the problems connected with the current civil procedure can also be perceived in the complexity and the structural relations with respect to the inadequate size of the staff as well as material necessities of the judicial system. These deficiencies were caused by politically conditioned different ideas about the administration and the management of justice in the Slovak Republic.

It was the reasons mentioned above that led to the idea in the office of the Ministry of Justice of the Slovak Republic to create a new Procedure Code. A re-codification committee was created, made up of experts in all legal professions. These experts after a ten-month period created the legislative intent which should also be introduced to the Czech legal professionals through this contribution. The re-codification committee agreed that it was necessary to create three codes instead of one Civil Procedure Code with one Code regulating the dispute proceedings (Civil Dispute Code), the second should cover the other proceedings than disputes, which has been up to now known as the non disputes proceedings and the next code should be intended exclusively for the needs of the administrative justice (Administrative Procedure Code). 


\section{What Are the Most Important Changes Going to Be?}

At the time when the proposal of the legislative intent of the re-codification of the civil procedural law was being consulted by the experts, we were working on this contribution. The final version of the law will take into account the comments acquired through the consultation and it will be this version which will have to be approved by the Government of the Slovak Republic. However, we can point out several proposed changes as presented in the proposed legislative intent.

The contradictory principle is to be made stricter. This principle is based on the fact that the plaintiff in the civil lawsuit insists on the satisfaction of the claims made and the defendant has the same contradictory goal. Thus in the civil lawsuit there is a social conflict solved through the process of two parties standing against each other. This conflict is controlled by the court and thus the court is supposed to actively participate in the proceedings. The court is not merely a passive observer of the conflict between the two parties but it influences and controls the conflict in order to provide protection to the party that needs the protection under the law. The contradictory principle can also be understood as a battle which motivates the parties to actively use the means of attack and defense.

This principle is to be applied mainly in the process of providing evidence. The proposed legal regulation covering the court procedure and the process of providing evidence will differ significantly from the current regulation. The court will only be allowed to use the evidence suggested by the litigants. Exceptionally the court will also be allowed to use the evidence that was not suggested by the litigants. This will be possible only in those cases where it is important for reaching the verdict, however, only in cases where the law explicitly says so. This is done in order to protect he weaker party such as e.g. the employee or the consumer.

There is an important change to be made as far as the content of the code is concerned. According to the experts proposing the legislative intent this change can contribute to the efficiency and speediness of proceedings. This change consists in the increase of requirements for the procedural activity of litigants and the procedural responsibility for the sanctions imposed in cases of procedural inactivity. In order to illustrate the point it should be said that the litigants themselves frequently lengthen the proceedings, sometimes they do so intentionally. In cases when the litigants avoid the proceedings, obstruct the justice and do not cooperate with the court in the proceedings in order to reach a speedy judgment, it should be made possible to sanction such litigants through a new institute under the new Civil Procedure Code. For example in cases when the litigant does not meet the deadline and does not take the necessary procedural steps he/ she would lose the opportunity to take this step later in the proceedings (proce- 
dural preclusion). This measure would help to secure greater interest to cooperate with the court on the part of the litigants. As a matter of fact the continuity and speediness of the proceedings does not always depend merely on the will and activity of the court, or even the judge. The Ministry of Justice of the Slovak Republic as the authority responsible for the administration of justice frequently receives complaints about delays in the proceedings which, after a deep analysis of the case, seem to have been caused by the procedural passivity of the litigant who subsequently mistakenly complains about the 'wrong' procedure of the court. When talking about the obstruction of justice in proceedings, it has to be said that the court proceedings which are often, from the subjective viewpoint of the litigants characterized as lengthy. However, it is not only this subjective viewpoint, but also certain objective attributes such as e.g. meeting certain noneffective procedural deadlines which often cause the inability of the litigants to apply their rights within a reasonable period of time. As a result of the traditional overload of the courts, the courts cannot even objectively cope with the number of cases to be solved. The aim of the newly proposed legislation is to eliminate such situations.

The professionalization within the civil proceedings is going to be another important change. This means apart from other things that the professional legal representation in the proceedings at the courts of second instance and in the proceedings at the courts of first instance e.g. in accordance with the principle ratio valoris and ratio causae should be made obligatory. The selection of the proceedings, which could only be conducted if the litigants are represented by an advocate (or the compulsory representation by an advocate except for the cases when the litigant himself does not have a legal education or his employee /member/ who is acting on his behalf), could be conditioned by the sum of money on the one hand (the sum of money that is being claimed by the plaintiff) on the other hand it could also be conditioned by the type of matter that is being tried - i.e. the subject of the dispute. With the compulsory legal representation the courts may be freed from certain obligations connected with the filing of complaints which are not complete, clear and do not contain all the required formal elements. The responsibility of the court to exercise some of its duties towards the litigants is also minimized with the obligatory legal representation. At the same time the initiator of the legislative intent takes into account the necessity on the part of the represented litigant to financially participate in the proceedings. The proposed legislation will also contain the adjustment of social aspects of law towards the way to the court.

The new legal regulation will strengthen the existing elements, which were supposed to intensify the court proceedings. According to the proposal of the legislative intent a form of so-called pre-trial hearing will be introduced. The existing legal regulation contained in the $\$ 118$ clause 2 of the Civil Procedure Code should be developed into this institute (especially the provisions saying 
that after the beginning of the proceedings the litigants will present or complete their proposals and the senate chairman or the judge sitting alone will announce the results of the preparation of the proceedings. Subsequently the chairman of the senate or the judge sitting alone will state, in accordance with the results of the previous proceedings, which are the important facts of the case presented by the litigants which can be regarded as matching, which are the important facts of the case which are contradictory and which of the proposed evidence will be carried out and which will not be carried out by the court even though they have been suggested by the litigants). The court should at this stage determine obligatorily which of the statements made by the litigants should be considered as legally significant with a subsequent challenge addressed to the litigants in order to signify clearly which evidence they suggest in order to prove these facts. The other following statements and suggested evidence will not be taken into account. The existing right of the court under the $\$ 100$ clause 1 of the Civil Procedure Code,(in cases when the proceeding has started, the court has to proceed even without any further proposals so that the case is dealt with and closed as soon as possible) will be transformed into the duty of the court to state the legal assessment of the case and focus the process of evidencing solely on the presentation of conflicting facts between the litigants.

Re-codification will also take into account the fact that the current society is modernized and uses electronic means of communication. The new regulation of the court procedure and the litigants must be based on and accept new means of communication. The existing legal regulation only reflects the new means of communication marginally, which leads to an increased expenditure on the court proceedings. Electronic mail, telecommunication, websites and data files have to gain a greater importance, which will make the conducting of proceedings easier and more economical.

In cases of dispute proceedings the legislative activity, from the viewpoint of the content, must be above all focused on the regulation of delivering the writ of summons on the natural persons. The recent legal regulation coped effectively with the problems connected with the delivery on the legal persons and natural persons, businessmen, through a strict delivery fiction. The corresponding delivery fiction on the natural persons who are not businessmen would probably be connected with impossibility to appear before the court on the constitutional law level on the one hand, however, on the other hand it is necessary to transfer the responsibility on the citizens for the impossibility to deliver the writ of summons on the citizens at the place of their official residence in accordance with the specific regulation. The existing legal regulation results in lengthy and financially demanding finding of the whereabouts of the litigants and thus it is practically ineffective and non-uniform. Therefore it is necessary to regulate the way of finding out the whereabouts of the litigant, on whom it was not possible to deliver the writ of summons to the address of the litigant's registered place of residence. 


\section{The Remedial Measures after the Re-codification of the Civil Procedural} Law

The system of remedial measures is an exceptionally important system of legal institutes used for the securing of review of the court's decision and proceedings, which preceded the decision. The current Slovak legal regulation distinguishes between standard remedial measures and extraordinary relief depending upon the fact whether the remedial measure is aimed against valid decision or not. One of the standard remedial measures is - according to the Civil Procedure Code - the appeal and one of the extraordinary relieves is appellate review, new trial and extraordinary appellate review.

The revision of the appellate review proceedings based on the combination of reviewing and cassatian system will belong among the most important changes to the new legal regulation of remedial measures. It will also be based upon the fact that the extraordinary appellate review is going to be removed from the system of remedial measures. This step is going to reflect the ruling of the European Court of Human Rights (hereinafter referred to as ECHR) considering the extraordinary appellate review as a redundant element inconsistent with the Convention on the Protection of Human Rights and Fundamental Freedoms (hereinafter referred to as European Convention). This opinion has appeared and is based upon the overall character and nature of the extraordinary appellate review as the application of this institute in the dispute proceedings has raised doubts as a result of the unequal positions of the two parties, violation of the principle of legal certainty and the violation of the principle of res iudicata.

The system of remedial measures will be represented even after the re-codification process by the standard remedial measures and the extraordinary relieves in the same way as it was up to now.

Appeal will still serve as the standard remedial measure whereas the action to compel somebody to act and the appellate review will serve as the extraordinary relieves. In the legislative intent there is also a proposal to introduce a new institute of procedural remedy - remonstrance. Through the remonstrance it will be possible to challenge the judicial resolution on proceedings along with some other procedural resolutions fully listed by the law. After the complex and detailed proposal of the proceedings has been made by the court of first instance, especially the legal regulation of the proceedings, it will be decided whether the remonstrance will be a standard remedial measure or the measure of procedural protection (i.e. not regarded as a remedial measure), such as e.g. protest or objections.

\subsection{Appeal}

It has been proposed that the appeal should be kept as a standard remedial measure. In connection with the legal regulation dealing with proceedings at the 
court of first instance the different types of modifications of decisions against which it is not possible to appeal could be also considered. It is also necessary that the responsibility of the litigants in the appellate proceedings should be strengthened through the concentration in the appellate proceedings. Then it is also important to think about a new division of competencies between the court of the first instance and the court of appeal. It is also necessary to consider the fact that in some cases it should be the judge sitting alone who should be allowed to decide about the appeal. In dispute proceedings it is necessary that the court should stick to the principle of incomplete appeal.

\subsection{Appellate Review}

The appellate review will be used as a remedial measure serving above all as a measure to remove the deficiencies that could lead to a confusion and wrongful legal assessment of the case. This measure should be used in accordance with the regulation specifically defining the circumstances that will have to be taken into account.

Taking into account the fact that it was proposed that the institute of the extraordinary appellate review should be cancelled the appellate review should be made more accessible. It is possible that the applicability should be widened so that it could also apply to the valid decisions made by the court of first instance. It would also be convenient if the Supreme Court of the Slovak Republic was allowed to decide about the admissibility of the appellate review for crucial legal purpose.

There are several possible alternatives for the defining of the admissibility of appellate review. First it could be regulated based on the type of decision made by the court (deformity, conformity) as it is now under the current legal regulation, or it could only be conditioned by the essential legal meaning and thus it will be specifically defined (such as e.g. in Austria or the Czech Republic). The specific defining of the admissibility will also be based on the new legal regulation dealing with proceedings at the court of first instance.

When defining the admissibility the current constant judicial decisions as well as the foreign legal regulation will be taken into account. In this context it will also be inevitable to explicitly regulate by the law the inadmissibility of the appellate review against verdicts through which it was decided about the divorce of a marriage, through which the marriage was declared as void or through annulment of the marriage (in order to rule out the possibility of bigamy). In other family law matters the appellate review will be admissible for certain reasons such as confusion, however, the inadmissibility of the appellate review will be kept under the $\$ 238$ clause 4 of the current Civil Procedure Code. ${ }^{2}$

2 The appellate review is not admissible in cases regulated by the Family law and by the amendments 
It is suggested that in the appellate review proceedings the cassation-reviewing principle should be kept. The reviewing principle in the legal regulations of the EU member states is frequently praised also by the Council of Europe. It is also another way to conduct the proceedings more effectively, economically and speedily. In cases of the reviewing principle (i.e. the possibility to change the decision) there is an issue arising connected with the necessity to find out the facts of the case and its potential changes - if the appellate court is supposed to decide according to the state at the moment when the court is about to decide about the appellate review. The second variant is to make a decision according to the state of the day of issuing of the challenged decision with possible changes in the facts of the case being eventually solved within the execution of the judgment.

\subsection{Action Filed in Order to Renew Proceedings}

This type of action will be designed as a remedial measure the primary aim of which is to review the facts of the case on which the original valid judgment was based. At the same time those reasons the are the results of the implementation recommended within the region of the European Region will be the reasons belonging to the category of renewal reasons [current reasons according to the $\$$ 228 clause 1 letter d), e), f) of the Civil Procedure Code].

There are not going to be any big changes made during the process of the formation of the new legal regulation in comparison with the existing valid and effective legislation.

As far as the terminology is concerned, when dealing with the newly proposed system it is possible to refer to this institute as to the action filed in order to renew the proceedings, as it is the remedial measure which is addressed to the court which has given the verdict and then subsequently after the admission there is going to be another proceeding at the court of the first instance. This term was used in the Slovak Republic up to the year 1950 and currently it is also used in the Czech legal regulation which has been inspired by the Austrian and German regulations. In the historical and legal context as in the comparative context it is a completely conform solution.

\subsection{Extraordinary Appellate Review}

As it has been outlined above it was proposed that the extraordinary appellate review should be completely crossed out from the system of extraordinary remedial measures. The reasons for this step are dealt with in the following part of the contribution.

to some laws apart from the judgment upon the limitation or removing of parental rights and duties, or the discontinuance of their execution, upon the acknowledgement of parental rights and duties to the minor parent of a child, upon the establishing paternity, upon the denial of paternity or upon the adoption. 
If we compare the regulations of selected European countries it can be said that in the Western European countries ( e.g. Austria, Germany, Italy, Denmark, Finland) person other than the litigant or the enjoined party cannot intervene into the procedural autonomy of another litigant. This trend is only typical of the post-communist countries. However, the Czech Republic does not have a specific legal regulation covering this analogical remedial measure either. If we take a look at the ruling of the ECHR it seems that the application of this extraordinary remedial measure can lead to the conclusion that the ECHR will consider the result of the proceedings achieved due to the application of an extraordinary remedial measure as violating the principles of due procedure. The attitude of the ECHR can be easily seen in the decision made in a case Brumarescu v. Romania, Tripon v. Romania (No. 1), Tripon v. Romania (No. 2). Based on the decisions made in these cases it is obvious that according to the ECHR an intervention of the general prosecutor into a private law dispute is an aggravating factor. Although the state authority acts based on an impulse, filing an extraordinary remedial measure is always dependent upon the discretion of the general prosecutor.

In this context it is also important to point out the Recommendation of the Ministries' Committee of the Council of Europe adopted in 1984 called The Principles of Civil Procedure for Better Functioning of Justice. Under this document the valid legal regulation should aim to make the civil procedure easier and faster. These principles also recommend certain measures in order to prevent the misuse of remedial measures.

However, the extraordinary appellate review is currently well regulated under the Civil Procedure Code of the Slovak Republic ( $\$ 234 \mathrm{e}$ - if the general prosecutor, based on the impulse given by the litigant, a person influenced by the decision of a court or a person harmed by the decision of the court, finds out that the valid decision of the court violated the law and if it is required because of the protection of rights and interests of natural persons protected by the law, legal persons or the state and at the same time it is not possible to secure this protection through different legal means, then the general prosecutor shall file an extraordinary appellate review against such a decision of the court). The admissibility of this institute is not so limited as in the case of appellate review, thus there is an enormous space for the review of the court's decisions. The time limit for the filing of extraordinary appellate review is one year from the validity of the court's decision, which disturbs the principle of the legal certainty which has long been pushed forward in the rulings of the ECHR. The litigant in the proceeding of extraordinary appellate review also, in comparison with the appellate review, does not have to be represented by the advocate and the proceeding of the extraordinary appellate review is not chargeable. The attributes to be mentioned last can be, for the person giving an impulse to the general prosecution, 
a reason for such a procedure if it is taken into account that there is "nothing to lose".

An area which is very broadly regulated is the possibility to file a motion to an extraordinary appellate review for a person other than the litigant, such as e.g. a person influenced by the decision of the court or a person who has been harmed by the decision of the court. Such a blurred definition does not give any concrete idea how the specific criteria should be interpreted. Under this regulation the institute of the suspension of enforcement of challenged decision has a very privileged position compared to the institute of appellate review. Under the $\$ 243 \mathrm{ha}$ if the general prosecutor files an extraordinary appellate review and at the same time files a motion to suspend the enforcement of the challenged decision, the enforcement of the challenged decision is postponed because of the delivery of the extraordinary appellate review to the appellate court.

On the other hand the legal regulation of the extraordinary appellate review is often duplicate with the legal regulation of appellate review. Based on such a definition of a remedial measure it is possible to review a wide range of valid decisions of courts in a period that is unreasonably long without any duty to pay a court fee, and also without the duty of the litigant to be represented by an advocate if the litigant is only a person giving an impulse and in the proceeding there is a general prosecutor. That is why among the legal professionals there has been a debate about the justifiability of the extraordinary appellate review. Last but not least the criticism also uses the fact claiming that the strong procedural position of the general prosecutor is historically based upon the specific situation in the Czechoslovakia in the 1950's, i.e. in the period when the justice was repressively controlled by the state.

\subsubsection{The Extraordinary Appellate Review and the ECHR}

ECHR repeatedly came to conclusion that as a result of the cancellation of valid court decision based on the decision about the extraordinary appellate review there as the violation of the article 6 of the European Convention. The decisions about the extraordinary appellate review are characteristic as a matter of fact by the fact that based on the procedural step of a person other than the litigant even in cases when the impulse was given by one of the litigants a valid and legally binding decision of the court is cancelled. The ECHR decided that there was an inconsistency with the ECHR's rulings in cases of Kutepov and Anikeyenko v. Russia (decision of October 25, 2005), where the execution of the power to ask for an extraordinary review consisted explicitly in the discretion of an official and his own evaluation of the arguments while considering whether or not the case requires an extraordinary review. In cases when a valid and legally binding decision of the court was declared void based upon the filing of a general prosecutor (or another person respectively) who was not the litigant the ECHR

3 The ECHR's rulings were processed for the purposes of the Re-codification committee. 
declared that the whole court proceedings was, in such cases, frustrated. An institute, very similar to the institute of extraordinary appellate review regulated by the Civil Procedure Code was subject to scrutiny by the ECHR in a famous case Tripon v. Romania No. 1 (the ruling of the $23^{\text {rd }}$ September 2008). The ECHR in the ruling declared that in the matter tried the general prosecutor did not act out of his own initiative but acted based on the claim of one of the litigants. This was a private law dispute and in addition both litigants were entitled to the same right to ask the general prosecutor for an initiation of a review proceeding. ECHR pointed out again to its settled rulings saying that the right to a fair trial guaranteed by the article 6 clause 1 of the European Convention must be interpreted in the light of the Preamble of the European Conventions which, among other things, declares the principle of democratic state respecting the rule of law as the common heritage of all the states that signed the European Convention. In the ruling Tripon v. Romania the ECHR stressed that one of the basic aspects of a state respecting the rule of law is the principle of legal certainty requiring apart from other things that in cases where the courts decided in accordance with the law (giving a final verdict) about the subject of a dispute the decision should not be challenged. The ECHR in the case mentioned above did not take into account the fact that both parties could have asked the general prosecutor for an intervention into their private law dispute. The ECHR denoted the intervention of the general prosecutor into such a dispute as an aggravated factor because, even though the state official acted upon the impulse of the litigant, the filing of the extraordinary appellate review was left entirely upon the discretion of the general prosecutor. The ECHR therefore arrived at the conclusion that the cancellation of the challenged valid legally binding decision of the court breached the plaintiff's right to the fair court proceeding according to the article 6 clause 1 of the European Convention.

The ECHR stated that the violation of the principle of the legal certainty had occurred and as a result of this also the violation of the right to a fair trial under the article 6 clause 1 of the European Convention in cases when the reviewed extraordinary remedial measure was not available to the litigants but was available merely to the general prosecutor and as a result of the filing of this measure the relevant court decided to freeze the whole court proceeding which resulted in a valid legally binding decision which represented res iudicata. In the sense of the decision-making practice of the ECHR, even the time limit for the application of the procedural step did not have any effect upon the conclusion described above. As a result of this time limit the valid decision of the court was cancelled as the time limit is not under the ruling of the ECHR enough to justify the existence of such an institute. It is not even enough to pronounce compatibility of the extraordinary appellate review with the article 6 clause 1 of the European Convention. 
In the case of SC Masinexportimport Industrial Group SA v. Romania (verdict of December 1, 2005) the ECHR stated that irrespective of the fact that there was a one-year time limit period introduced as a special measure for the filing of the extraordinary appellate review, this institute still unjustifiably collides with the principle of legal certainty, with two other elements of this remedial measure being preserved. The ECHR pointed out the incompatibility of these elements with the principle of legal certainty when dealing with another case Brumarescu v. Romania (the extraordinary appellate review 1. was not available to the litigants, but to the general prosecutor only and at the same time the right to file this remedial measure was not subject to any time limit and 2. as a result of the successful application of this measure the Supreme Court frustrated the whole court proceeding which was ended by the court's decision representing the principle res iudicata).

In the case of Asito v. Moldavia (verdict of November $\left.8^{\text {th }}, 2005\right)$ the ECHR dealt with a legal institute similar to the extraordinary appellate review regulated by the Slovak Civil Procedure Code, i.e. the motion to cancellation through which the general proecutor was allowed to challenge any final decision of a court. Thus it was possible, through this procedure, to reach the cancellation of final and enforceable decisions of a court. The ECHR in this respect stated that such a procedure violates the principle of legal certainty.

The relevant ECHR's rulings show that the system of remedial measures as enshrined in the legal order of the contractual party to the European Convetnions must inevitably be in harmony with the requirements listed under the article 6 of the European Convention. In the case of Sitkov v. Russia (verdict of Januay 18, 2007) the ECHR referred to its previous decision from the ruling in the case of Sovtransavto Holding v. Ukraine, under which the court systems, which are characteristic of objection proceedings, saying it is possible to repeatedly cancel the final decisions of courts, are not compatible with the principle of legal certainty, which is one of the fundamental principles of the state respecting the rule of law under the article 6 clause 1 of the European Convention. Thus the ECHR within its decision-making activity has more than once pronounced the incompatibility of such extraordinary remedial measure with the principle of legal certainty and stated that the article 6 clause 1 of the European Convention have been violated.

The ECHR also pronounced a violation of the article 6 clause 1 of the European Convention in those cases when a new review of a case was ordered because of the fact that there was a different assessment of the case in comparison with the legal assessment of the state courts, which dealt with the case and gave a final meritorious verdict. The ECHR, in relationship to the cancellation of the verdict of the court of lower instance through the reviewing of the case Sitkov v. Russia stated that, taking into account the circumstances of the case submitted, the article 6 clause 1 of the European Convention was breached through the cancellation 
of final legal and valid decision of the court. In this case the primary reason for the "re-opening" of the proceeing the need to judge once again the facts of the case. This was done on the basis of the impulse given by an official who was not a litigant. In connetion with these cases the ECHR mainly pointed to the legal uncertainty arising as a result of the cancellation of the final court's decision. For example in the case of Stere and others v. Romania (verdict of February 23, 2006) the ECHR stated that, in case, the litigant challenged the valid decision of the court merely for the purpose of reaching a new analysis, judging and decision in the case the cancellation of legally valid verdicts would lead to creating the environment of legal uncertainty resulting in the citizens' lack of confidence in the legal system and consequently the lack of confidence in the state respecting the rule of law. In this context the ECHR reminded that the principle of the state respecting the rule of law as one of those principles of democratic society is contained in all the articles of the European Convention. The principle of a democratic state respecting the rule of law is based on the condition of respecting the principle of legal certainty especially as far as court decisions representing the principle res iudicata are concerned. No litigant is entitled to require the court to assess the court's decision that is legally binding merely for the purpose of getting the chance for new dealing with the case, assessment and verdict. The ECHR also stressed that through the cancellation of a legally valid decision the environment of legal uncertainty would lead to the lack of confidence of the public in the legal system and subsequently lack of connfidence in the state as the one respecting the rule of law.

The ECHR in the case of Abdullayev v. Russia (the verdict of February 11, 2010) stressed that for the sake of legal certainty implicitly contained in the article 6 of the European Convention, final decisions should remain, in general, "untouched". That is why they should only be cancelled for the purposes of relieving crucial faults. However, according to the ECHR, the fact that there are two different views on the subjet of the proceeding should not be considered as such a fault. Thus the ECHR came to the conclusion that such a reason cannot be regarded as a good reason for assessing the case for a second time.

In the case of Sutyazhnik v. Russia (verdict of July 23, 2009) the ECHR ruled that the decision of a court reresenting res iudica can only be reviewed on condition that there has been a serious fault made and as a result of this the decision should be reviewed.

In the case of Cornif v. Romania (verdict of January 11, 2007) the ECHR stated that it had come to the conclusion while judging the case that this was a typical example of the existence of two different legal opinions on the same subject of proceeding, which in no case allows the court to cancel a valid and legally binding decision of the court. In addition to this in that case which involved a legal dispute between private subjects there was nothing that would represent circumstances of such a crucial and important interest which would entitle the 
court to cancel the valid decision of the court in accordance with the principles declared in the case of Ryabykh ( Ryabykh, $\$ 52$ ).

In many cases the argumentation from the case of Kot v. Russia has been used. Under this argumentation the litigants in a civil court proceeding inevitably have a different opinion on the application of the substantive law. The disagreement with the assessment of the case by the court of first instance and by the appellate court cannot be regarded as extraordinary circumstances which would entitle the court to cancel a legally binding and enforceable decision and subsequently "re-opening" of the proceeding. That is why the ECHR also stated that the article 6 clause 1 of the European Convention was violated in these cases.

It is possible to sum up by saying that in the sense of the ECHR's rulings the justifiability of the application of the extraordinary remedial measure for the purpose of cancellation of the court's decision and the admissibility of the diversion was accepted as non-violating the principle of the legal certainty only in such cases when during the proceedings there were serious procedural mistakes made by the acting courts, i.e. there were some defficiencies in proceedings, however, not in cases of different assessment of the facts of the case and different factual and legal conclusions made by the litigants against the factual and legal assessment pronounced by the court in a due process.

The application of the extraordinary remedial measure is, under the legal order of the Slovak Republic, directly available to the litigants in cases of serious mistakes on the part of the court. It can be applied on the basis of some of the appellate review reasons enshrined in the $\$ 237$ of the Civil Procedure Code. The appellate review is, as a matter of fact, admissible against every decision of the appellate court if:

a) the court has made a decision about a thing that does not belong to the competency of the courts;

b) the person who presented himself as a litigant did not have the capacity to be called a litigant;

c) the litigant did not have the procedural capacity and was not properly represented;

d) the same case has already been decided or in the same case the proceeding has already started;

e) if the motion to begin the proceeding has not been filed, although it was necessary under the law to do so;

f) the right to appear before the court was removed from the litigant through the procedural steps taken by the court;

g) the case was decided by an expelled judge, or the court was improperly occupied, the senate decided instead of the judge sitting alone

If there are some of the points or so-called "reasons for confusion" mentioned above connected with the decision-making of the court upon the legal claims 
of the litigants, then the litigant himself can apply the extraordinary remedial measure in the form of appellate review. However, if there were no such serious mistakes made by the acting courts, then the application of the extraordinary appellate review is, in the light of the rulings of the ECHR outlined above, incompatible with the article 6 of the European Convention.

For these reasons the initiator of the legislative intent decided to omit completely the institute of the extraordinary appellate review as an extraordinary remedial measure in the proposal of the new legal regulation. However, it is still not clear and final whether such a step will be taken or not. The omission of the extraordinary appellate review as well as some other changes briefly outlined above are conditioned by the legislative intent which must first be approved by the Government of the Slovak Republic. It will only be this version which is supposed to be binding for the framing of the specific provisions in the new form of the law. 